\title{
ZTRÁTA CTNOSTI - ZTRÁTA NORMY? \\ Ke koncepci mravních norem Alasdaira MacIntyra
}

\author{
Martin Cajthaml
}

\section{Úvod}

Cílem článku je odpovědět na otázku, lze-li na základě výkladu etiky ctností, předloženém ve vlivné knize Alasdaira MacIntyra Ztráta ctnosti, ospravedlnit existenci, popř. platnost mravních norem. ${ }^{1}$ Otázku po jejich platnosti zde klademe na pozadí námitky, jež je vǔči etice ctností často uplatňována, a sice že tato etika nedostatečně zohledňuje významné postavení, které mravní normy (tedy mravní požadavky, př́ikazy a zákazy) v etice zaujímají. ${ }^{2}$ Společensko-politicky relevantním kontextem, v němž je odpověd na výše uvedenou otázku významná, je pak téma lidských, popř. přirozených práv člověka. Jak známo, Všeobecná deklarace lidských práv vyhlášená Valným shromážděním OSN v prosinci 1948 se stala modelem pro mnohé následující smlouvy a konvence a je dnes obsažena v ústavách mnohých států. V našem prostředí máme stále v živé paměti vystoupení Charty 77 , která připomínala komunistickému režimu, že má dodržovat základní lidská práva, k čemuž se zavázal podepsáním helsinských paktů z roku 1975. V tomto kontextu je zarážející MacIntyrovo tvrzení, že ,žádná taková práva neexistují a víra v ně je

1 A. MacIntyre, After Virtue. A Study in Moral Theory, Notre Dame $2007^{3}$. Citovat budeme z českého překladu: týž, Ztráta ctnosti, přel. P. Sadílková - D. Hoffman, Praha 2004. Termínem ,norma“ rozumíme výrok konstatující to, co „má být“ (v blíže nespecifikovaném smyslu). „Mravní normou“ rozumíme výrok, který říká, že něco „má být“" ve specificky mravním slova smyslu. Platností mravních norem rozumíme spolu s Kelsenem vlastní bytí těchto norem: říkáme-li o normě, že platí, neudáváme podle Kelsena její vlastnost, ale její vlastní (ideální) bytí (srv. A. Leinweber, Gibt es ein Naturrecht? Beiträge zur Grundlagenforschung der Rechtsphilosophie, Berlin 1965, str. 280). To znamená, že výroky „norma A platí“ a „,existuje norma A“ lze považovat za ekvivalentní.

2 Srv. např. J. Prinz, The Normativity Challenge. Cultural Psychology Provides the Real Threat to Virtue Ethics, in: The Journal of Ethics, 13, 2, 2009, str. 117-144; R. Hursthouse, Virtue Ethics, odd. 3: Objections to Virtue Ethics, dostupné na: https://plato.stanford.edu/entries/ethics-virtue/\#ObjeVirtEthi. 
totéž jako víra v čarodějnice či jednorožce“. ${ }^{3}$ Položíme-li si otázku po důvodech této pozoruhodné skepse vůči existenci, popř. platnosti lidských práv, dospějeme tím mimo jiné k výše položené otázce ohledně statusu a zdůvodnění eticky relevantní normativity ve Ztrátě ctnosti. ${ }^{4}$ Ř́káme mimo jiné. Směrodatný vliv na MacIntyrovu skepsi vůči veškeré moderní (čti: liberální) morálce, za jejíž bytostnou a vysoce důležitou součást MacIntyre obhajobu individuálních lidských práv považuje, ${ }^{5}$ má

3 A. MacIntyre, Ztráta ctnosti, str. 89. Tezi, že lidská práva jsou pouhou fikcí, opakuje MacIntyre i ve svém posledním díle. Srv. A. MacIntyre, Ethics in the Conflicts of Modernity. An Essay on Desire, Practical Reasoning, and Narrativity, Cambridge 2016, str. 77. Své stanovisko zde oproti Ztrátě ctnosti kvalifikuje, aniž by jej ovšem úplně vyjasnil. Kvalifikace spočívá v jeho tvrzení, že uznává existenci nepodmíněných zákazů, které platí nezávisle na existenci pozitivního práva. Tím se výslovně přiznává k přirozenoprávní tradici, a to, jak je zřejmé z jeho jiných děl, k její (volně) tomistické verzi. Srv. A. MacIntyre, Plain Persons and Moral Philosophy, in: K. Knight (vyd.), The MacIntyre Reader, Notre Dame 1998, str. 136-152. MacIntyre však ve svém posledním díle popírá, že by přirozenoprávní normy platily proto, že existují individuální lidská práva. To je pozoruhodná teze, která by si zasloužila hlubší rozbor. Není například jasné, proč by diskurz lidských práv nemohl být legitimní způsob, jak v moderní době poukazovat na realitu přirozenoprávních norem. To je způsob rozšířený v katolické intelektuální tradici 20. století, již MacIntyre nepochybně znal. Tento způsob je navíc vyjádřen i v řadě dokumentů učitelského úřadu církve, jíž byl MacIntyre po své konverzi ke katolicismu členem. MacIntyre nepopírá, že dovolávání se lidských práv vedlo v řadě případů k pozitivním společensky-politickým důsledkům. Podle něj je však možné dospět ke stejně pozitivním důsledkům i na základně argumentace, která nevychází z fiktivních konstruktů, za něž lidská práva považuje, ale z pojmů spravedlnosti a společného dobra. Srv. A. MacIntyre, Ethics in the Conflicts of Modernity, str. 78.

4 Ztráta ctnosti je prvním směrodatným vyjádřením toho, co bylo následně označováno jako MacIntyrův filosofický projekt. Jeho dalšími reformulacemi, jež zahrnují řadu dílčích korektur, ba dokonce odvolání některých předchozích stanovisek, jsou knihy: A. MacIntyre, Whose Justice? Which Rationality?, Notre Dame 1988; týž, Three Rival Versions of Moral Inquiry, Notre Dame 1990; týž, Dependent Rational Animal, Chicago 1999; týž, Ethics in the Conflicts of Modernity. MacIntyrův retrospektivní pohled na vlastní filosofický projekt a jeho vývoj viz týž, Dependent Rational Animal, str. x-xi. Je pozoruhodné, že dvacet pět let po vydání Ztráty ctnosti MacIntyre přes všechny dílčí korektury původního stanoviska upozorňuje, že ,dosud nenašel důvod k tomu, aby se vzdal hlavních tezí vyslovených ve Ztrátě ctnosti" (A. MacIntyre, Prologue. After Virtue after a Quarter of a Century, in: týž, After Virtue, str. ix). MacIntyre se sám za představitele etiky ctností nepovažoval. Přesto je spolu s Elisabeth Anscombovou považován za jejího nejvýznamnějšího představitele. Obšírná analýza tohoto směru etického myšlení viz J. J. Sanford, $B e$ fore Virtue. Assessing Contemporary Virtue Ethics, Washington 2015.

5 Srv. např. A. MacIntyre, Ethics in the Conflicts of Modernity, str. 77. 
totiž marxismem inspirovaný způsob vidění liberálních morálních principů a idejí coby forem tzv. falešného vědomí. ${ }^{6}$

\section{Vyvození norem z faktů}

Nejvýznamnější argument pro existenci mravních norem ve Ztrátě ctnosti nacházíme v pasážích, kde MacIntyre zdůvodňuje tvrzení, že hodnotící soudy lze za určitých okolností platně vyvozovat $\mathrm{z}$ výroků konstatujících fakta. ${ }^{7}$ Autor zde netvrdí pouze to, že takové platné vyvozování je možné principiálně, ale že je možné také specificky, pokud jde o hodnotící soudy v oblasti etiky. ${ }^{8}$ Podmínkou takového vyvození však je, že lidská přirozenost má vedle své faktické stránky objektivně stanovený cíl či účel. Jinými slovy, hodnotící soudy patřící do oblasti etiky lze vyvodit z výroků konstatujících fakta, pokud je lidská přirozenost pojata jako objektivně teleologická. Za tohoto předpokladu, tvrdí MacIntyre, je pojem ,člověk“ podobný pojmům „hodinky“ či „farmáŕ““

6 Srv. především tamt., str. 93-100. MacIntyre vidí koncepce individuálních lidských práv právě v této marxistické perspektivě a považuje je spolu s velkou částí liberální morální teorie za fiktivní teoretické konstrukty, které zastírají pravou povahu společenských a ekonomických vztahů jak svým sociálně privilegovaným tvůrcům, tak vykořist'ované většině. Domníváme se, že nebezpečím tohoto pohledu je, že svádí k tomu spatřovat v nárocích na universální etickou racionalitu tzv. falešné vědomí i tam, kde tomu tak není, a že MacIntyre není vůči tomuto pokušení zcela imunní, jde-li právě o různé formy toho, co ve svém posledním díle nazývá „Morálka“ (Morality), tedy hlavní morální koncepty evropského osvícenství 18. století.

7 MacIntyre přitom nehovoří o „mravních normách“, ale o tom, že z faktuálních premis lze platně vyvodit „morální“, popř. „,hodnotící závěry“. Srv. A. MacIntyre, Ztráta ctnosti, str. 74-75. Jeho argumentace je ovšem kritikou humovské teze, že z toho, co ,je“", nelze vyvodit to, co „má být“, tedy to, co v tomto textu označujeme jako „normy“. Navíc, jak ukázal Husserl, hodnotící soudy, o nichž hovoří MacIntyre, jsou ekvivalentní soudům normativním. Srv. E. Husserl, Logická zkoumání, I, Prolegomena $k$ čisté logice, přel. F. Karfík - K. S. Montagová, Praha 2009, str. 51-56. MacIntyrova argumentace ve prospěch teze, že hodnotící závěry lze vyvozovat z faktických premis, a to i v oblasti etiky, tedy přinejmenším implikuje obhajobu platnosti jistého typu etické normativity. Z Husserlových analýz např́iklad vyplývá, že MacIntyrem zmiňovaný (hodnotící) soud „Pouze přesné hodinky jsou dobré hodinky“ je ekvivalentní (normativnímu) soudu „Hodinky mají jít přesně“.

8 A. MacIntyre, Ztráta ctnosti, str. 74-77. Zasvěcené shrnutí dějin diskuse o tom, lze-li vyvozovat (mravní) normy z faktů, viz S. J. Jensen, Knowing the Natural Law. From Precepts and Inclinations to Deriving Oughts, Washington 2015, str. 1-7. 
v tom, že se jedná o tzv. „funkční pojem“.9 Funkční pojem je takový, jehož denotát je vymezen z hlediska zdárného fungování ve specificky určeném funkčním rámci. Tato definice je pak tvrzením konstatujícím fakt, resp. je množinou takových tvrzení. Pokud referent funkčního pojmu nepodává v rámci vymezeného funkčního rámce dobrý výkon, lze tento nedostatek rovněž vyjádřit tvrzením konstatujícím fakta, resp. množinou těchto tvrzení. $Z$ takových faktuálních tvrzení pak lze platně vyvodit hodnotící soudy, ${ }^{10}$ přičemž tato možnost se vztahuje na všechny entity definované prostřednictvím funkčních pojmů. ${ }^{11}$

\section{Ctnosti, společenské praxe, narativita, tradice}

Jak už bylo řečeno, uvedená argumentace je podle MacIntyra platná i v etice, je-li lidská přirozenost pojata teleologicky. Ve Ztrátě ctnosti se však MacIntyre nesnaží rehabilitovat tradiční přirozenou teleologii - tzn. pojetí, podle nějž všechny lidské bytosti směřují k cíli či účelu, který je dán jejich příslušností k lidskému druhu -, nýbrž tzv. teleologii společenských praxí, potažmo teleologii ukotvenou v narativně konstituovaném životním smyslu. ${ }^{12}$

9 A. MacIntyre, Ztráta ctnosti, str. 76.

10 „Z faktických premis jako,tyto hodinky jsou značně nespolehlivé a nepřesné nebo ,tyto hodinky jsou příliš těžké pro pohodlné nošení vyplývá platný hodnotící závěr, ,že toto jsou špatné hodinky‘. Z faktických premis jako ,má u této plodiny mnohem lepší výnosy na akr než všichni ostatní zemědělci v kraji‘, ,má nejlepší plán obnovy půdy, jaký byl kdy objeven'a ,jeho dojnice vyhrávají na zemědělských přehlídkách vždy první cenu“ vyplývá platný hodnotící závěr, že je ,dobrým zemědělcem“.“ Tamt., str. 75.

11 Tamt., str. 76.

12 Mohlo by se zdát, že MacIntyre v této věci později změnil názor. Uvádí totiž například, že mu studium Tomáše Akvinského ukázalo, že každý pokus založit lidské dobro čistě v sociálních kategoriích, tedy v praxích, tradicích a narativní identitě lidského života, je v posledku neuspokojivý. Praxe, tradice, atd. totiž podle něho mohou fungovat pouze proto, že lidské bytosti mají cíl či účel, k němuž jsou zaměřeny v důsledku své druhové přrirozenosti. Uznání této druhově specifické zaměřenosti na cíl či účel MacIntyre tamtéž označuje za „,metafyzický základ“ svého pokusu založit etiku na společenských kategoriích. Srv. A. MacIntyre, Prologue. After Virtue after a Quarter of a Century, str. xi. Při bližším pohledu na MacIntyrovo chápání tohoto „metafyzického základu“ se však zdá, že nevylučuje osobní volbu vlastního nejvyššího cíle či účelu. Druhová přirozenost zde totiž vstupuje do hry pouze v tom smyslu, že formulace vlastního nejvyššího cíle či účelu musí respektovat druhově specifické přirozené sklony (Tomášovy inclinationes naturales interpretované 
Společenskou praxí13 míní MacIntyre ,,jakoukoli koherentní a komplexní formu společensky zavedené, kooperativní lidské činnosti, skrze niž se v rámci snahy o dosažení měřítek zdatnosti - měřítek, jež přísluší této formě činnosti, a zároveň jsou jí definovány - uskutečňují dobra inherentní této formě činnosti, díky čemuž se systematicky rozvíjejí jak schopnosti člověka k získání zdatnosti, tak př́íslušné koncepce cílů a dober" ${ }^{14}{ }^{14}$ Inherentní dobra jsou tedy zaprvé dobra, která prostřednictvím praxe vznikají a která odpovídají měřítkům excelence, charakteristickým pro tu kterou praxi. Inherentním dobrem společenské praxe, kterou nazýváme kompozice pro klasickou kytaru, je tak např́klad Úvod a variace na Mozartovo téma, op. 9 Fernanda Sory, zatímco inherentním dobrem společenské praxe, kterou nazýváme hra na klasickou kytaru, je třeba Breamova interpretace Brittenovy skladby Nocturnal.$^{15}$ Zadruhé jsou pak inherentní dobra ony aspekty života lidí účastnících se společenských praxí, v nichž se excelence těchto praxí vyjadřuje, tedy Sorův skladatelský život a Breamův život kytarového virtuosa. Inherentním

v duchu společenských praxí). Srv. A. MacIntyre, Whose Justice, Which Rationality?, str. 174. Zdá se tedy, že pozdní MacIntyre přes svůj deklarovaný tomismus nepojímá přirozenou teleologii tak objektivisticky, jak ji pojímal Tomáš. Potvrzuje to, jak se zdá, i způsob, jímž MacIntyre ve svém posledním díle chápe poslední cíl lidského života, tedy ono dobro, jehož dosažením se lidský život stává dokonalým a nic dalšího nevyžadujícím. Tímto dobrem je podle něj schopnost pravdivého sebepoznání. Viz níže, str. 97. MacIntyre se snaží tento svůj výklad prezentovat jako autentickou interpretaci Aristotela a Tomáše - ta však nevyznívá přesvědčivě. Srv. A. MacIntyre, Ethics in the Conflicts of Modernity, str. 54. Má-li MacIntyrovo pojetí posledního cíle lidského života vůbec nějakého předchůdce v klasických pozicích, pak je to nejspíš Sókratés. Říkáme-li „Sókratés“, myslíme tím to, co je s tímto jménem tradičně spojováno. To, co učil tzv. historický Sókratés, bylo, je a zřejmě zůstane předmětem sporů klasické filologie.

13 MacIntyrův technický termín „,social practice“ zde překládáme v souladu s existujícím překladem Ztráty ctnosti jako „společenská praxe“. Činíme tak proto, že tento překlad je v českém kontextu běžně užíván a nezdá se, že by existovala jednoznačně lepší alternativa. Tomu, co tento termín znamená, je však třeba rozumět z jeho definice, kterou uvedeme vzápětí, popř. z širšího kontextu jeho užití v MacIntyrově díle, nikoli ze sémantické analýzy výrazu „společenská praxe“. Tak je tomu ostatně u většiny filosofických odborných termínů.

14 A. MacIntyre, Ztráta ctnosti, str. 220. MacIntyre později rozšiřuje pojem společenských praxí i mimo oblast specificky lidské společenskosti a hovoří o společenských praxích delfínů, lvů či šimpanzů. Srv. A. MacIntyre, Dependent Rational Animal, str. 31.

15 J. Bream, 20th Century Guitar, RCA 1967. Srv. T. J. Green, Julian Bream's 20th Century Guitar. An Album's Influence on the Modern Guitar Repertoire, Riverside 2011, str. 63-75 (dostupné na: https://escholarship.org/uc/item/5rg2n57t). 
dobrem těchto praxí tak není soukromý život obou mužů, ani například chvíle strávené Breamem na kriketovém hřišti. ${ }^{16}$

MacIntyre pak vymezuje ctnost právě prostřednictvím pojmů společenské praxe a praxe inherentního dobra: „Ctnost je nabytá lidská vlastnost, jejíž vlastnění a uplatňování nám umožňuje dosáhnout dober, která jsou praxi inherentní a jejichž nepř́ítomnost nám účinně brání v dosažení takových dober." ${ }^{\text {17 }}$

MacIntyre si uvědomuje, že teleologie imanentní společenským praxím nestačí k tomu, aby dala lidskému životu onu jednotu, která je pro něj charakteristická a žádoucí. Život, jehož kontinuitu a smysl by tvořila pouze participace na společenských praxích, by totiž „,byl prostoupen př́liš mnoha konflikty a př́liš velkou svévolí“. ${ }^{18}$ MacIntyre poskytuje následující vysvětlení:

\begin{abstract}
„Nicméně i v životě ctnostného a disciplinovaného člověka může nastat řada okolností, kdy loajalita [allegiance] vůči jednomu ukazuje jedním směrem, a loajalita vůči jinému druhým směrem. Požadavky jedné praxe mohou být natolik neslučitelné s požadavky jiné praxe, že se člověk může ocitnout v situaci, kdy mezi nimi spíše osciluje, než aby rozumně volil.“19
\end{abstract}

Jako příklad lze myslet dilema ženatého vědce nebo umělce, který musí volit mezi požadavky, jež vznáší jeho profese a jeho rodinný život (umění, věda i rodinný život jsou společenské praxe v MacIntyrově smyslu).

Pojetí ctnosti založené pouze na teleologii společenských praxí tedy neposkytuje žádné kritérium, na jehož základě by bylo možné racionálně rozhodnout konflikty mezi nároky na loajalitu vůči eventuálně kolidujícím praxím. Proto se MacIntyre pokouší doplnit tento předběžný výklad ctnosti rozvedením pojmů narativity a tradice. ${ }^{20}$ Cílem tohoto výkladu

16 A. MacIntyre, Ztráta ctnosti, str. 221-223. MacIntyrovy vlastní příklady jsou z oblasti malírství.

17 Tamt., str. 224 (kurziva A. M.).

18 Tamt., str. 235 (kurziva A. M.).

19 Tamt.

20 Ve Ztrátě ctnosti MacIntyre pojímá pojmy narativity a tradice jako „obohacení" (enrichment), popř. doplnění (supplement) výkladu ctnosti založeného na pojmu společenské praxe. V Dodatku $k$ druhému vydání toto stanovisko reviduje. Uvádí, že ,žádnou lidskou vlastnost nelze považovat za ctnost, nesplňuje-li podmínky dosažené $v$ každém ze zmíněných tří stádii“". A. MacIntyre, Ztráta ctnosti, str. 319. Někteří autoři namítají, že vztah teleologie praxí a teleologie hledání dobra 
je ukázat, že teleologické pojetí lidského života lze koncipovat i mimo rámec přirozené teleologie, popř. Aristotelovy „metafyzické biologie“, a že i takto pojatý lidský život může být jednotný a smysluplný. Tento pokus založit teleologii na socialitě, nikoli na biologicko-metafyzicky pojaté druhové jednotě lidské přirozenosti, má ovšem řadu povážlivých důsledků. Např́íklad zahrnuje představu, podle níž „každé pojetí ctností souvisí s nějakou konkrétní představou narativní struktury či struktur lidského života“. ${ }^{21} \mathrm{Z}$ řečeného ovšem plyne, že např́íklad norma „Usiluj o ctnost a vyhýbej se špatnosti“"v rámci takového pojetí bud' má specifický obsah, avšak platí pouze v rámci dané narativní struktury, ${ }^{22}$ nebo platí universálně, avšak je zcela bezobsažná. Přitom není vyloučeno, že to, co pro jednoho člověka platí za ctnost, může být pro druhého špatnost, a naopak. ${ }^{23}$

je u MacIntyra ambivalentní. Srv. L. Downig - R. Thygpen, After Telos. The Implications of MacIntyre's Attempt to Restore the Concept in After Virtue, in: Social Theory and Practice, 10, 1984, str. 45-46. Tato kritika je však založena na chybném porozumění způsobu, jímž MacIntyre vztah obou typů teleologie ve skutečnosti pojímá. Srv. M. Cajthaml, Telos and Normativity. MacIntyre on Grounding Moral Norms (dosud nepublikováno). MacIntyre to tak sice výslovně neříká, ale je zřejmé, že pojmy narativity a tradice se uplatňují při řešení dilemat, před něž člověka staví protichůdné nároky různých společenských praxí tak, že takřka generují kritéria, na jejichž základě lze tato dilemata racionálně rozhodnout. Racionálně přitom znamená v souladu s tím, jaký př́íběh o svém životě - a svým životem - vyprávím, popřr. v souladu s tradicí, na jejímž základě chápu a tvořivě interpretuji otázku po dobrém životě.

21 A. MacIntyre, Ztráta ctnosti, str. 205. Viz také následující pasáž: „Chápeme-li lidský život jako cestu, na které procházíme různými obtížemi a různým nebezpečím, morálním i fyzickým, jež nás mohou potkat a s nimiž se potýkáme někdy lépe někdy hưře, tu s větší tu s menší měrou úspěchu, pak se ctnosti ukážou jako vlastnosti, jejichž vlastnictví a uplatňování má sklon vést člověka $\mathrm{k}$ úspěchu, a neřesti $\mathrm{k}$ neúspěchu. Každý lidský život pak bude ztělesňovat př́iběh, jehož struktura a podoba bude záviset na tom, co považujeme za obtíže a nebezpečí, a na tom, jak chápeme a hodnotíme úspěch a neúspěch, pokrok a jeho opak. Odpověd’ na tyto otázky bude znamenat explicitní i implicitní odpověd na otázku, co jsou ctnosti a co neřesti.“, Tamt., str. 170-171. Konec první citované věty je přeložen z anglického originálu. Původní český překlad je zde zcela chybný.

22 Zdá se, že tato struktura je podle MacIntyra variabilní nejen jako nadindividuálně platný kulturně-historický typ (viz jeho analýzy herojského pojetí smyslu života, jež stojí např. proti pojetí sofokleovskému), ale liší se dokonce od jednotlivce k jednotlivci. Na jednom z klíčových míst totiž autor uvádí: „, čem spočívá jednota individuálního života? Odpovědí je, že tato jednota je jednotou př́íběhu ztělesněného jednotlivým životem.“ Tamt., str. 255.

23 Že se zde nejedná o pouhou logickou možnost, naznačuje MacIntyrova snaha o to, aby integroval tzv. tragická dilemata do své koncepce etiky ctnosti. Tragická je 


\section{Spravedlnost, odvaha, pravdomluvnost, trpělivost}

Je třeba podotknout, že ne všechny ctnosti jsou podle McIntyra zdatnostmi, které člověka uschopňují k dosahování dober inherentních jednotlivým praxím. Součástí MacIntyrova pojetí ctností ve Ztrátě ctnosti jsou totiž také tzv. mravní ctnosti: spravedlnost, odvaha a pravdomluvnost. ${ }^{24}$ Ty nás podle autora neuschopňují $\mathrm{k}$ dosahování dober inherentních jednotlivým praxím, ale $\mathrm{k}$ tomu, abychom úspěšně vykonávali praxe vůbec, tedy bez ohledu na zvláštní povahu každé z nich. Jak MacIntyre upozorňuje, bez spravedlivého přístupu, elementární pravdomluvnosti a skutečného zájmu o věci, které jsou pro praxe důležité, se praxím nebude dařit.

Přestože tyto tři ctnosti mohou být $\mathrm{v}$ různých společnostech a kulturách vyjádřeny různě, jedná se podle autora o různá vyjádření téhož. ${ }^{25}$ Proto nelze tvrdit - jako v př́padě zdatností definovaných ve vztahu $\mathrm{k}$ inherentním dobrům jednotlivých praxí -, že obsah těchto tří mravních ctností (ve smyslu jejich kulturně-společenského invariantu) je relativní ve vztahu k narativním strukturám. To znamená, že norma „Usiluj o spravedlnost, statečnost a pravdomluvnost, a vyhýbej se jejich opakům“ je v rámci MacIntyrovy teorie ctnosti universálnější než příkaz „Bud’ dobrým farmářem“, „Bud’ dobrým otcem“ nebo „Bud’ dobrým šachistou".

Nakolik ovšem MacIntyre nevyvozuje hodnotu těchto tří ctností z vnitřní hodnoty příslušného typu jednání, popř. cítění, $\mathrm{k}$ němuž nás uschopňují, nýbrž z toho, že podmiňují zdárný rozvoj společenských praxí, činí ji relativní vůči hodnotě společnosti, v níž se praxe uskutečňují. Povšimněme si, že tím problematizuje jeden podstatný rys tradice, kterou se jinak snaží oživit. Platón, Aristotelés i Tomáš Akvinský totiž učili, že o mravní ctnosti je třeba usilovat kvůli nim samým, nikoli pro

taková volba, kdy žádná z obou (či více) alternativ není správná. I v takové situaci, tvrdí MacIntyre, se lze chovat lépe a hůře. Nikoli však v tom smyslu, že zvolíme lepší $\mathrm{z}$ alternativ (to je $\mathrm{v}$ daném prrípadě nemožné), ale $\mathrm{v}$ tom, že tu alternativu, kterou zvolíme, můžeme lépe či hůře uskutečnit (tamt., str. 260-261). Těmito úvahami, jak se zdá, MacIntyre připouští, že skutečně může nastat situace, kdy to, co je z hlediska jedné z alternativ (tragické) volby ctnost, je z hlediska druhé špatnost, a naopak. MacIntyrův př́íklon k tezi, že skutečně existují tragické životní situace, tzn. situace, kdy můžeme volit pouze mezi dvěma či více špatnými alternativami, se projevuje i v tom, že nevylučuje existenci vzájemně nesouměřitelných hodnotových hierarchií. Viz níže str. 88.

24 Tamt., str. 224-227.

25 Tamt., str. 226. 
jejich užitečnost pro dosažení něčeho dalšího. ${ }^{26}$ MacIntyre by mohl své pojetí mravních ctností skloubit s tradicí například tím, že by od sebe odlišil důvod bytí těchto ctností od důvodu jejich žádoucnosti. Mohl by tedy tvrdit, že tyto ctnosti vznikají (alespoň ve své elementární podobě) v kontextu příslušných praxí, protože jsou jednoduše dispozicemi, které tyto praxe vyžadují k tomu, aby se mohly rozvíjet. Již existující ctnosti by pak byly žádoucí kvůli sobě samým, nikoli kvůli své užitečnosti pro zdar praxí. MacIntyre však takovou distinkci nečiní, takže relevantní pasáže v jeho výkladu vyznívají tak, že užitečnost pro praxe je důvodem samotné žádoucnosti mravních ctností. Tento přístup má zjevně utilitaristický nádech, což může působit ironicky vzhledem k MacIntyrovu tvrzení, že jeho výklad ctností ,je až pozoruhodně neslučitelný s jakýmkoli utilitaristickým pohledem“.27

Tím, že MacIntyre vyvozuje hodnotu výše uvedených mravních ctností z jejich užitečnosti pro rozvoj společenských praxí, navíc zatemňuje důvod, proč jsou ty to ctnosti označeny jako „mravní“. Zdaleka ne všechna dobra inherentní jednotlivým praxím jsou totiž mravně relevantní. ${ }^{28}$ Přitom je zřejmé, že jednání mající za účel dobro, které není mravně relevantní, samo není nositelem specificky mravní hodnoty (pokud ovšem zdrojem mravní hodnotnosti není jiný činitel, např. to, že svým činem plním slib, který jsem dal). Mravně hodnotná pak ovšem není ani trvalá dispozice jednat tímto způsobem, což znamená, že daný habitus je sice určitou zdatností, nikoli však ctností ve vlastním slova smyslu, tedy mravní excelencí.

Ačkoli není snadné přesně říci, co činí jistá dobra mravně relevantními, je poměrně snadné uvést příklady dober, která mravně relevantní jsou, a těch, která mravně relevantní nejsou. Některá dobra inherentní pro hru na klasickou kytaru, jako např́klad vzorná technika levé ruky,

26 Sókratés v Ústavě hájí tezi, že spravedlnost patří k dobrům, jež stojí za to, abychom si je získali pro ně sama, a to mnohem více než pro jejich účinky. Platón, Resp. II,367c7-9. Aristotelés učí, že ctnostné jednání je třeba volit kvůli němu samé-

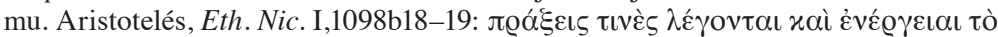

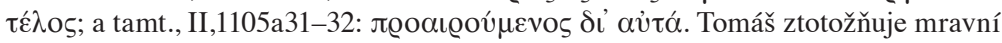
ctnost s bonum honestum (Summa theol. II-II,q.45). Bonum honestum přitom definuje jako dobro, o nějž je třeba usilovat kvůli němu samému. Srv. M. Waldstein, Dietrich von Hildebrand and St. Thomas Aquinas on Goodness and Happiness, in: Nova et Vetera, 1, 2003, str. 425-431.

27 A. MacIntyre, Ztráta ctnosti, str. 231.

28 K pojmu mravně relevantní hodnoty viz D. von Hildebrand, Christian Ethics, New York 1953, str. 169-179 a 265-281; týž, Moralia, Regensburg 1980, str. 21-50. 
mravně relevantními jistě nejsou. Proto také úsilí věnované rozvoji a upevnění této techniky není mravně relevantní činností. Tudíž rovněž habitus uschopňující levou ruku k takřka dokonalému pohybu po kytarovém hmatníku je sice obdivuhodnou a obtížně získatelnou dispozicí, není však mravní ctností. Oproti tomu jistá dobra inherentní společenské praxi, kterou obvykle nazýváme rodinný život, mravně relevantní zjevně jsou, např́iklad péče o nemocného partnera nebo výchova dětí. Proto je činnost, v níž o tato dobra usilujeme, mravně dobrá a nečinnost, popř. nedostatečná činnost, mravně špatná. A tedy i trvalá získaná dispozice starat se správným způsobem o potřebné členy vlastní rodiny je mravní ctností. Pochopitelně existují i situace, kdy se dobro, které samo o sobě není mravně relevantní, mravně relevantním stává. Např́íklad solidní technika levé ruky se stává mravně relevantním dobrem v situaci, kdy je hra na kytaru prostř̌edkem výdělku, na němž závisí výživa hráče i rodiny. $\mathrm{V}$ tomto případě však mravní relevance nelpí přímo na technice ruky samé, ale na péči o sebe a rodinu, k níž je technika $\mathrm{v}$ dané situaci prostředkem. Přestane-li jím být, pozbyde mravní relevanci.

Jakkoli je rozlišení na mravně relevantní a mravně irelevantní dobro v podstatě triviální, uniklo nejen MacIntyrově pozornosti, ale i pozornosti některých jeho přívrženců. ${ }^{29}$ Ve světle tohoto rozlišení je zřejmé, že teleologie založená na praxích je sice schopná odůvodnit určitou normativitu (hodnotící soudy lze totiž, jak ukazuje výše uvedený MacIntyrův argument, platně vyvodit z faktuálních tvrzení), ovšem tato normativita není výlučně - a snad ani převážně - etická. Kdyby MacIntyre rozlišil mravně relevantní praxe od praxí mravně irelevantních, popř. mravně relevantní inherentní dobra od dober mravně irelevantních, mohl by říci, že mravní normy zakládají pouze mravně relevantní praxe, popř. dobra. Navíc by mohl přesvědčivěji reagovat na námitky Samuela Schefflera a Roberta Wachbroita. Scheffler MacIntyrovi vytýká, že z jeho výkladu ctností plyne, že velcí šachisté nemohou být padouši a že velký šachista, jenž je padouch, nemůže získat žádné z dober inherentní šachu. ${ }^{30}$ MacIntyre je schopen přesvědčivě zodpovědět pouze druhou ze Schefflerových námitek. ${ }^{31}$ První z námitek je ovšem podstatnější. Jiným

29 Např́íklad Knight předpokládá, že člověk získává mravní ctnost tím, že rozvíjí schopnost získat dobra inherentní praxím. Viz A. MacIntyre, The MacIntyre Reader, str. 10 .

30 Týž, Postscript to the Second Edition, in: After Virtue, str. 274.

31 A. MacIntyre souhlasí se Schefflerem v tom, že tento důsledek z jeho pojetí skutečně vyplývá. Tvrdí však, že není absurdní. Tvrzení, že velký šachista, který je padouch, nemůže získat žádné z dober inherentních šachu, je pravdivé, protože 
způsobem ji zformuloval Wachbroit, když poukázal na to, že MacIntyre musí „,prijimout možnost, že jednat zdatně [virtuously] nemusí vždy znamenat jednat správně“. 32

Kdyby tedy MacIntyre rozlišil mravně relevantní a mravně irelevantní dobra, potažmo praxe, mohl by snadno a přesvědčivě vysvětlit, jak je možné, že zdatný člověk může jednat nesprávně, potažmo jak někdo může být velký šachista a zároveň padouch. Někdo může být zdatný, nakolik je schopen skvěle vyhovět standardům excelence určité mravně irelevantní praxe, například šachu, a současně jednat nesprávně, nakolik neodůvodněně zanedbává povinnosti, které pro něj plynou z jiné, tentokrát mravně relevantní praxe, například z praxe rodinného života. Zaujetí pro mravně irelevantní praxi přitom může být vlastním důvodem zanedbávání praxe mravně relevantní. Takový člověk je zdatný, zároveň je však jeho jednání mravně problematické. Tím je současně zodpovězena i Schefflerova otázka, jak může někdo být současně velký šachista i padouch.

Vůči této argumentaci lze namítnout, že aplikací uvedeného rozlišení mezi mravně relevantní a irelevantní praxí implicitně popíráme východisko, které si MacIntyre stanovil ve Ztrátě ctnosti, a sice založit etično na realitě praxí. S touto námitkou nelze než souhlasit. Je však třeba podotknout, že sám MacIntyre později dospívá k závěru, že etiku nelze vyvodit pouze ze společenských daností (praxí, narací a tradic), a že tedy musí mít „metafyzický základ“. ${ }^{33} \mathrm{~K}$ tomu lze dodat, že i sama teleologie praxí předpokládá formální (a v tom smyslu „metafyzické“) vymezení dobra jako toho „oč všichni usilují“. Pokud by dobro nebylo formálně pojato jako předmět touhy, popř. usilování, nebyla by ani dobra inherentní praxím tím, o co stojí za to usilovat. Bez této ,přitažlivosti“ inherentních dober by pak byla normativita imanentní praxím zbavena svého opodstatnění. Tedy ani založení etiky ve společenských kategoriích, o něž se MacIntyre ve Ztrátě ctnosti pokouší, není zcela bez „metafyzických“ předpokladů, tzn., není nezávislé na kategoriích, které společenské realitě předcházejí a které z ní nejsou odvoditelné.

Dále lze namítnout, že MacIntyre předpokládá výše uvedené rozlišení mezi mravně relevantní a irelevantní praxí, když připouští, že mohou

takový šachista ve skutečnosti usiluje pouze o vítězství. To je však vnějším dobrem této praxe.

32 R. Wachbroit, After Virtue. A Study in Moral Theory, by Alasdair MacIntyre [review], in: The Yale Law Journal, 92, 1983, str. 572.

33 Viz pozn. 12. 
existovat praxe, které jsou ve skutečnosti špatné, resp. že praxe umožňují, ba někdy dokonce vyžadují mravní kritiku. ${ }^{34} \mathrm{Na}$ tuto námitku je třeba odpovědět, že uvedené výroky pouze ožrejmují fakt, že MacIntyre nepovažuje praxe za jediný zdroj mravního dobra, potažmo že připouští zdroj mravního dobra, který je na praxích nezávislý. Výše jsme však netvrdili, že MacIntyre považuje praxe za jediný zdroj mravní normativity. Pouze jsme upozornili, že mají-li být praxe přesvědčivým zdrojem mravní normativity, je $\mathrm{v}$ jejich rámci třeba rozlišit mravně relevantní a mravně irelevantní praxe. Uznává-li MacIntyre vedle teleologie praxí a narativně konstituovaného telu lidského života ještě jiný zdroj eticky relevantní normativity, nestává se tím poukaz na potřebu rozlišit mravně relevantní a mravně irrelevantní dobra, resp. praxe, bezpředmětným. Jak ještě uvidíme, tímto dodatečným zdrojem etické normativity ve Ztrátě ctnosti budou názory společenství na to, co je zcela nepř́ipustné. ${ }^{35}$

Spravedlnost je však pro MacIntyra nejen jednou ze tří ctností, které podmiňují zdar praxí obecně, ale i ctností, která předpokládá, stejně jako např́íklad trpělivost, určité hierarchické uspořádání dober. ${ }^{36}$ Jelikož MacIntyre ve Ztrátě ctnosti odmítá Aristotelovu „metafyzickou biologii“, stejně jako jakýkoli jiný metafyzický princip takového axiologického uspořádání, a současně si uvědomuje, že jeho teorie společenských praxí není s to takové celkové uspořádání inherentních a vnějších dober odůvodnit, hledá řešení v již zmíněné narativní struktuře lidského života a $\mathrm{v}$ telu, $\mathrm{k}$ němuž narativně utvořená jednota lidského života směřuje. Subjektivnosti narativity coby principu takto pojaté životní jednoty odpovídá odmítnutí existence jediné platné, objektivní hodnotové hierarchie. ${ }^{37}$ To však znamená, že norma „Usiluj o spravedlnost“,

\footnotetext{
34 A. MacIntyre, Ztráta ctnosti, str. 234.

35 Viz níže, str. 91.

36 A. MacIntyre, Ztráta ctnosti, str. 236-237.
}

37 Toto odmítnutí je implicitně př́ítomno na více místech Ztráty ctnosti. Jedním z nich je pasáž, v níž MacIntyre odmítá utilitaristický kalkul. Odmítnutí je opřeno o argument, že tento kalkul předpokládá homogenitu pojmů štěstí, což je podle MacIntyra iluze: „Slast, již nabízí sklenice Guinnessu, není stejná jako slast, již si přivodíme koupáním na Crane Beach, přičemž koupání a pití nejsou dva různé prostředky k dosažení téhož stavu. Štěstí, které je typické pro řeholní způsob života, není totéž jako štěstí, které je typické pro život vojenský. Nebot' různé slasti a různá štěstí jsou do značné míry nesouměřitelné: nemáme žádná měřítka kvality nebo kvantity, jimiž bychom je porovnávali. Kritérium slasti mi nepoví, zda pít nebo se jít koupat, a kritérium štěstí za mne nerozhodne, zda žít životem mnicha nebo vojáka.“ Tamt., str. 83. Jak se zdá, přesvědčení o tom, že neexistuje jediná objektivní hierarchie dober pro všechny lidské bytosti, implikuje, že MacIntyre straní 
popř. „Usiluj o trpělivost“ bude v rámci MacIntyrova výkladu ctností přikazovat materiálně jiný typ jednání, popř. cítění, v rámci různých hodnotových hierarchií. Tedy i v př́ípadě takto pojatých ctností bude platit, že právě vysvětlené implicitní normy jsou bud' universálně platné, ale bezobsažné, nebo mají specifický obsah, ale jsou platné jen v rámci určité hodnotové hierarchie, resp. vzhledem k určité narativní struktuře.

\section{Hledání dobra}

MacIntyrův výklad ctností ve Ztrátě ctnosti ovšem zahrnuje ještě další důležitý prvek. Je jím poukaz na existenci ctností, které uschopňují člověka k filosofickému hledání dobra. ${ }^{38}$ MacIntyre zde spojuje myšlenku hledání dobra s pojmem tradice: ${ }^{39}$

Homérovi a Sofokleovi ve sporu s Platónem a Aristotelem, pokud jde o otázku, může-li být lidský život jednotný a harmonický, nebo musí-li být nutně tragický. Tamt., str. 185-186 a 192-193. Odmítnutí jedné objektivní hierarchie dober jako čehosi př́liš naivního je nejexplicitněji přítomno v MacIntyrově odpovědi Robertu Wachbroitovi. Tamt., str. 320-322. Otázka, která si zaslouží bližší prozkoumání, kterou se zde však nemůžeme zabývat, zní, zda MacIntyrův následný obrat k tomismu a s tím související „,metafyzické založení“ teorie praxí, znamená rovněž změnu názoru na otázku existence jediné objektivně platné hodnotové hierarchie. Domníváme se, že nikoli.

38 „Proto je třeba porozumět ctnostem jako dispozicím, které nejen zachovávajî praxi a umožňují nám dosáhnout pro praxi inherentních dober, ale také nás udržují na cestě hledání dobra tím, že nám umožňují překonat obtíže, nebezpečí, pokušení a komplikace, s nimiž se setkáváme, a poskytují nám tak stále hlubší sebepoznání i rostoucí poznání dobra. Výčet ctností bude proto obsahovat ctnosti potřebné pro udržení takového druhu domácnosti a politického společenství, v němž mohou lidé společně usilovat o dobro a ctnosti potřebné pro filosofické zkoumání povahy dobra." Tamt., str. 256.

39 Překvapivé je toto spojení například pro ty, kdo znají Patočkovu interpretaci Sókrata. Sókratés zosobňující ,život v otázce“ je u Patočky postaven proti ,pouhé" tradici coby životu v úpadku, zkostnatělému setrvávání na osvědčených jistotách. Sókratés chce sice podle Patočky obnovit tradiční mravní ideál, ale novými prostředky filosofického tázání; chce rozbít petrifikované názory na lidské dobro svých současníků. U MacIntyra je tradice uchopena opačně než u Patočky. Tradice není symbolem nereflektovanosti, bezduché rutiny, ale naopak představuje nadosobní kontinuitu filosofického hledání dobra. S Patočkou lze říci, že tradice je podle MacIntyra nadosobně pojatý život v otázce. K MacIntyrově pojmu tradice viz např. M. Kuna, MacIntyre on Tradition, Rationality, and Relativism, in: Res Publica, 11, 2005, str. 255-262. 
„Živá tradice je tedy historicky rozsáhlá a do společnosti integrovaná diskuse, a to diskuse zčásti právě o dobrech, jež tuto tradici utvářejí. Usilování o dobra se $\mathrm{v}$ rámci tradice rozpíná na generace, někdy na řadu generací. Hledá-li proto jednotlivec svá dobra, činí tak obecně a příznačně $v$ rámci kontextu definovaném tradicemi, jejichž je jeho život součástí, a to platí jak o dobrech inherentních praxi, tak o dobrech jednotlivého života. “40

Ve svých pozdějších pracích MacIntyre podrobně rozvíjí myšlenku různých „tradic etického zkoumání“ “ ${ }^{41}$ Zdůrazňuje především, že neexistují žádná všem racionálním osobám bezprostř̌edně přístupná nahlédnutí do podstaty tohoto dobra. Každé mravní poznání je možné jen v rámci určité tradice etického zkoumání. Důraz na to, že mravní poznání je vždy imanentní určité tradici zkoumání, mu pak vynesl výtku z relativismu. MacIntyre však v tomto ohledu relativista není. Netvrdí, že v etice či v jiných oblastech nemůže existovat objektivně platné poznání. Upozorňuje pouze, že takovéhoto poznání nebylo dosud dosaženo, avšak má smysl o něj usilovat. Taková „zdokonalená věda“ (perfected science) je dokonce přirozeným cílem, popř. účelem každého skutečného vědeckého poznání. ${ }^{42} \mathrm{~S}$ touto teleologicky zaměřenou vizí vědeckého zkoumání je pak u MacIntyra spojeno přesvědčení, že aristotelsko-tomistické pojetí vědy je tomuto ideálnímu cíli, popř. účelu zatím nejblíže.

Záměrem tohoto pojetí není tedy relativizace dobra, ale spíše obhajoba teze, že s výjimkou formálních principů jako je zákon sporu nebo nejvyšší princip praktického rozumu (Tomášovo bonum faciendum, malum vitandum) jsou veškeré poznatky, které o dobru a platnosti etických norem máme, provizorní ${ }^{43}$ Jinými slovy, tyto poznatky jsou zatím kladeny pouze dialekticky a mohou být modifikovány v důsledku pokroku dosavadního stavu poznání. Definitivně jisté budou až ve stádiu ,zdokonalené vědy“, v němž se však zatím nenacházíme, a ani není v dohledu. ${ }^{44}$ To v konečném důsledku znamená, že ctnosti, které nás disponují k hledání dobra (v rámci určité tradice jeho zkoumání), nás budou disponovat

\footnotetext{
40 A. MacIntyre, Ztráta ctnosti, str. 259.

41 Týž, Three Rival Versions of Moral Inquiry.

42 Na této myšlence je založena jeho teleologie vědeckého zkoumání. Týž, First Principles, Final Ends and Contemporary Philosophical Issues, in: týž, The MacIntyre Reader, str. 171-201.
}

43 M. Cajthaml, Telos and Normativity.

44 Tamt. 
k postupně se prohlubujícímu poznání, aniž nám ovšem umožní poznat dobro a mravní normy s definitivní platností.

Ve světle tohoto pozdějšího vývoje MacIntyrova myšlení můžeme konstatovat, že ani zařazení ctností uschopňujících k hledání dobra neimplikuje závazné přiznání $\mathrm{k}$ určitým materiálním mravním normám: bud’ je (nejvyšší) mravní princip (bonum faciendum) obsahově prázdný, a pak je universálně platný a apodikticky jistý, anebo mají mravní normy určitý obsah (jednotlivé předpisy přirozeného zákona), pak jsou ale platné pouze s větším či menším stupněm pravděpodobnosti.

Než přejdeme k závěru, je třeba upozornit ještě na jeden bod MacIntyrovy úvahy, který je v dané souvislosti relevantní. MacIntyre ve Ztrátě ctnosti při svém výkladu ctností u Aristotela zmiňuje i zákony obce. Při této př́ležitosti poukazuje na to, že pro dosažení společného dobra je třeba dvou hodnotících postupů: na jedné straně je třeba hodnotit ty schopnosti, které napomáhají uskutečnění tohoto dobra (tedy pozitivně hodnotit ctnosti), na druhé straně je třeba označit za nepř́ípustná taková jednání, která uskutečnění tohoto společného dobra znemožňují, popřr. významně ztěžují. ${ }^{45}$ Tuto pasáž lze chápat tak, že MacIntyre uznává, že vedle normativity imanentní praxím a životnímu telu jednotlivců je třeba zvažovat i normativitu mravního zákona. Mravní zákon má, jak MacIntyre upozorňuje, výlučně povahu zákazů. Př́ílady, které autor uvádí, jsou vražda nevinného, krádež, křivopřísežnictví a zrada. Z prŕíslušné pasáže však není úplně jasné, jedná-li se o pozitivní zákony kodifikované legislativním orgánem daného společenství, nebo o předpisy tzv. přirozeného práva, které pozitivním normám předcházejí a jsou na nich nezávislé. MacIntyre se později hlásí k přirozenoprávní koncepci v duchu Tomáše Akvinského, přirozenoprávní normy však chápe, podobně jako Aristotelés v právě diskutované pasáži, pouze jako zákazy, nikoli př́kazy jednat určitým způsobem. ${ }^{46}$

45 „Přehled ctností, hlásaných takovým společenstvím, by občany poučoval o tom, jaké činy jim zjednají zásluhy a čest; přehled zákonem stanovených provinění by je poučoval o tom, jaké činy se budou považovat nikoli za prostě špatné, ale za nepř́ípustné.“ A. MacIntyre, Ztráta ctnosti, str. 178-179.

46 Viz výše, pozn. 3. 


\section{Zpět k argumentu ve prospěch možnosti vyvozovat normy $\mathrm{z}$ faktů}

Vrat'me se k MacIntyrově argumentaci ve prospěch tvrzení, že normy lze vyvozovat z faktů, a to i v oblasti etiky. Připojíme k ní několik kritických poznámek, které se nabízejí ve světle předchozích úvah. Nejprve upozorněme, že platnost hodnotících soudů, které MacIntyre uvádí jako př́klady platných vyvození norem z faktů, je relativní vzhledem k dané společenské praxi. Např́íklad výrok „Joe je dobrý farmář“ je hodnocením Joa v kontextu farmářství. Toto hodnocení je tedy závislé na měřítku excelence, které je imanentní této praxi. Z faktuálních premis „má u této plodiny mnohem lepší výnosy na akr než všichni ostatní zemědělci v kraji“, „má nejlepší plán obnovy půdy, jaký byl kdy objeven“ a ,jeho dojnice vyhrávají na zemědělských přehlídkách vždy první cenu“ atp. tedy lze podle MacIntyra platně vyvodit hodnotící soud „Joe je dobrý farmář“. ${ }^{47}$

Upozorněme však, že z něj nelze platně vyvodit hodnotící soud „Joe je dobrý člověk“ (v mravním smyslu slova). Obtíž MacIntyrovy argumentace tedy spočívá v tom, že nakolik jsou dobra inherentní určitým praxím mravně irelevantní, jsou hodnotící predikáty, jež lze platně připsat osobám na základě jejich schopnosti dosahovat těchto dober výjimečně zdařilým zpo̊sobem, bez specificky mravního obsahu. Jinak řečeno, pozitivní hodnotící predikáty připsané těmto osobám kvůli excelenci, kterou prokazují na základě měřítek hodnocení, která jsou imanentní určitým praxím, nepřipisují těmto osobám specificky mravní kvality. Je tomu tak proto, že normativní prvek, který je obsažen v každé společenské praxi kvůli jejímu teleologickému zaměření, není mravně relevantní, nejsou-li mravně relevantní dobra, která jsou inherentní dané praxi. Proto např́íklad imperativ „Bud dobrým farmářem“, který je imanentní praxi farmaření, je sice nepochybně normou, nejedná se však o normu etickou (mravní), přičemž taková norma z něj ani nemůže být platně vyvozována.

Lze tedy vyslovit následující námitku podobnou té, která se týkala možnosti založit na teleologii praxí mravní normy: nakolik společenské praxe nesměřují k uskutečnění mravně relevantních dober, je možnost, založená na teleologické struktuře těchto praxí, platně vyvodit hodnotící soudy ze soudů faktuálních irelevantní pro otázku, mohou-li být mravní normy z faktů platně vyvozovány. Povšimněme si, že př́klady, na nichž

47 Viz výše, pozn. 10. 
MacIntyre ukazuje legitimitu vyvozování norem z faktů, jsou funkční pojmy „hodinky“ a „farmáŕ“. V této souvislosti je třeba podotknout, že řada mravních ctností může být užitečná, chceme-li se stát farmáři, a že chodit opakovaně pozdě, protože člověku jdou špatně hodinky - a nestará se, aby si koupil nové - je zlozvyk, a tedy mravní prohřešek. Na dobrých hodinkách ani na dobrém farmáři jako takových však není nic dobrého ve specificky mravním smyslu slova.

Hypoteticky lze ovšem uvažovat o tom, zda by byla MacIntyrova argumentace ve prospěch možnosti vyvozovat mravní normy z faktů přesvědčivější, pokud bychom rozlišili mravně relevantní dobra inherentní praxím od dober irelevantních a řekli, že pouze z faktuálních výrokủ týkajících se něčí schopnosti dosahovat mravně relevantních inherentních dober lze platně vyvozovat mravní normy. Avšak i kdybychom uvážili tuto možnost, byli bychom postaveni před vážné obtíže. Zmíním jen tu nejdůležitější.

V rámci MacIntyrova výkladu vztahu mezi teleologií praxí a etickou normativitou by norma „Usiluj o mravně relevantní dobro A inherentní praxi X“ byla platná pouze podmíněně. Z MacIntyrova pojetí normativity založené na teleologii praxí totiž vyplývá, že je věcí osobní volby stát se vykonavatelem té či oné praxe. Je-li tomu tak, pak každá norma založená na teleologii dané praxe je závazná pouze pro toho, kdo tuto praxi vykonává. Jelikož je ale výkon dané praxe výsledkem jeho svobodné volby, je i závaznost dané normy podmíněná touto volbou. Jinými slovy, určité normy založené v teleologii praxe pro mě platí, protože jsem se na základě předchozího rozhodnutí stal jejím vykonavatelem. Pokud bych se rozhodl praxi nevykonávat, normy by pro mě závazné nebyly.

Není obtížné si představit, jak by MacIntyre reagoval na tuto námitku. Jistě by upozornil, že výkon některých praxí není věcí osobní volby, ale je pro dobrý lidský život nezbytný. Při úvaze nad touto možnou reakcí tak bude užitečné rozlišit dva typy „nezbytnosti“, které by MacIntyre mohl mít na mysli. Jedním z nich je čirá nevyhnutelnost, diktovaná nutností přežít či jinou faktickou nutností. Důvodem pro výkon dané praxe by v takovém případě bylo pouhé přitakání dané nevyhnutelnosti, nikoli uznání mravní oprávněnosti nároku této praxe na to, aby se do ní člověk zapojil. Proto by výkon této praxe nemohl být mravně záslužný. Mravně záslužné by ovšem nebylo ani úsilí o uskutečnění dober, která jsou této praxi inherentní. Pokud by tedy výkon praxe $\mathrm{X}$ byl nezbytný ve smyslu faktické nevyhnutelnosti, byl by příkaz „Účastni se praxe X“ bezpodmínečně platný. Nejednalo by se však o mravní normu. Totéž by pak platilo pro normu „Usiluj o dobro A inherentní praxi X“. Nezbytnost 
praxe ve smyslu faktické nevyhnutelnosti tedy vede k uznání existence nepodmíněné normy, není to však norma mravní. Proto je předpoklad, že některé praxe jsou nezbytné ve smyslu čiré nevyhnutelnosti, irelevantní jako reakce na výše uvedenou námitku, že mravní norma „Usiluj o dobro

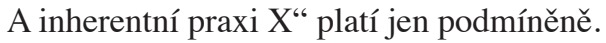

Nezbytnost praxe však může, zadruhé, znamenat, že účast na této praxi je nepodmíněně přikázána jistou mravní normou. I v tomto případě by mravní norma „Usiluj o dobro A inherentní praxi X“ byla nepodmíněně platná, přičemž by se navíc, na rozdíl od prvního případu, jednalo o normu mravní. Její nepodmíněnost by pak byla důsledkem toho, že platí mravní norma „Účastni se praxe X“, a nikoli toho, že úsilí o dobro A nepodmíněně přikazuje teleologie imanentní praxi X. V takovém pojetí však realita společenských praxí nezakládá nepodmíněnou platnost mravních norem, ale naopak ji sama vždy již předpokládá. Námitka, že mravní normy typu „Usiluj o dobro A inherentní praxi X“ mohou být platné pouze podmíněně, by tak nejen nebyla vyvrácena, ale byla by naopak potvrzena.

Jiným problémem příkladů, na nichž MacIntyre znázorňuje platnost tvrzení, že hodnotící soudy lze vyvodit z konstatování faktů, je trivialita jejich ověritelnosti: není obtížné ověřit přesnost hodinek, zjistit výnos na akr nebo výkonost dojnice. Má-li však být možné platně vyvodit z faktuálních výroků hodnotící soudy ve specificky mravním smyslu, tedy např́íklad výroky „X je spravedlivé“, „X je statečné“, „X je odvážné“, musí být v takovém vyvození nutně zahrnuty i výroky konstatující mentální stavy. Jak totiž uvádí již Aristotelés, mravní jednání nelze hodnotit bez toho, že bychom věděli „,v jakém stavu je ten, kdo jedná“ ${ }^{48}$ To znamená, že mravní hodnocení nějakého jednání zahrnuje také zjištění, jedná-li daná

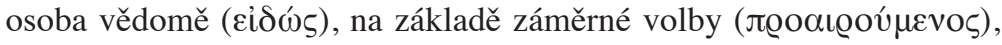
a na základě dobrého důvodu, tzn., zda volí ctnostné jednání kvůli němu

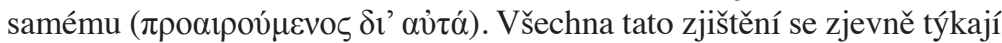
mentálních stavů, které jistě nelze ověřit tak snadno a jednoznačně jako fakta, která figurují v MacIntyrových př́ikladech. Tuto možnou obtíž by měla MacIntyrova argumentace reflektovat a vyrovnat se s ní. Náš autor ji však ani nezmiňuje, natož aby se s ní vyrovnával.

Dalším nedořešeným problémem je vztah mezi argumentací pro možnost vyvozovat hodnocení z faktů, jak se o ní hovoří v páté kapitole Ztráty ctnosti, a MacIntyrovým vlastním výkladem podstaty ctností, který se nachází až v mnohem pozdější čtrnácté kapitole. Především jde

48 Aristotelés, Eth. Nic. II,3,1105a30-5. 
o následující nejasnost: argumentace ve prospěch možnosti vyvozovat normy z faktů předpokládá, že pojem ,„člověk“ je pojem funkční (ve výše uvedeném smyslu). Toto tvrzení je pak v dané pasáži ospravedlněno poukazem na klasickou přirozenou teleologii. ${ }^{49}$ Jak jsme však už zmínili, sám MacIntyre takové pojetí nepřijímá a snaží se jej nahradit sociálně konstruovanou teleologií praxí, narativity a tradice.

Má čtenár̆ tento postup chápat tak, že teleologii obecné lidské přirozenosti je $\mathrm{v}$ argumentaci z páté kapitoly třeba retrospektivně nahradit teleologií praxí, narativit a tradic? Pokud by tomu tak bylo, jak si pak takové „nahrazení“ představit? Zřejmě bude třeba uplatnit pojmy „praxe“, „narativity“ a „tradice“ jako pojmy funkční. Jak to však provést, pokud má být výsledek srovnatelný s hodnotícími soudy, které lze podle MacIntyra vyvodit na základě předpokladu přirozené teleologie? Má-li člověk jako člověk svůj specifický cíl, popřx. účel, lze jako dobré a žádoucí označit vše (nebo aspoň mnohé z toho), co přispívá k jeho dosažení. To vše bude dobré a žádoucí pro všechny lidi, a to nezávisle na jejich subjektivních preferencích, popř. na jiných relativizujících faktorech. Lze pak srovnatelné universality a nepodmíněnosti mravních norem dosáhnout za pomoci teleologie praxí a v rámci určité tradice narativně ustaveného životního telu? MacIntyrovu odpověd’ na tuto otázku bohužel neznáme, protože se ve svém systematicky orientovaném výkladu ctností k argumentaci z páté kapitoly již nevrací. K tématu se nicméně vyslovuje z perspektivy svého pozdějšího „metafyzicky založeného“ stanoviska ve svém posledním díle..$^{50}$ Podívejme se na to, jakým způsobem.

\section{Pojetí významu hodnotových soudů a predikátů v MacIntyrově posledním díle}

Zatímco ve Ztrátě ctnosti šlo MacIntyrovi o demonstraci toho, že a jak lze normy vyvozovat $\mathrm{z}$ faktů, přičemž se vymezoval proti humovské tezi, že z toho, co je, nelze vyvozovat to, co být má, ve svém posledním díle chce především ukázat, že hodnotící soudy vypovídají o faktech. Přitom se vymezuje proti expresivismu, který realistický výklad významu hodnotících soudů a predikátů popírá. MacIntyre chce ukázat, že smyslem hodnotících soudů je vypovídat o realitě překračující mentální stavy toho, kdo tyto soudy vyslovuje. Své pojetí prezentuje jako alternativu

49 A. MacIntyre, Ztráta ctnosti, str. 76-77.

50 A. MacIntyre, Ethics in the Conflicts of Modernity. 
k emotivistickému, potažmo expresivistickému pojetí významu hodnotících soudů, přičemž expresivismus chápe jako sofistikovanější verzi emotivismu. ${ }^{51}$

Expresivismus vykládá význam hodnotících (a normativních) soudů tak, že tvrdit takový soud znamená vyjádřit svůj souhlas s ním. ${ }^{52}$ Jakkoli si ten, kdo hodnotící soudy vznáší, může myslet, že je vznáší proto, že odpovídají něčemu ve skutečnosti mimo realitu jeho vlastních mentálních stavů, tj. postojů, přesvědčení či tužeb, podle expresivistů je to klam. Jestliže například někdo tvrdí, že A je dobré, vyjadřuje tím svůj souhlas s tímto soudem, a vypovídá tak vlastně o sobě, resp. o svém postoji k soudu, který tvrdí. ${ }^{53}$ Podle expresivistů vynáším hodnotící soud jako výraz svého (často výslovně nereflektovaného) postoje ke světu, jako výraz toho, že přijímám platnost určitých (často nevyslovených) principů a norem. Přestože tedy expresivismus vznikl v reakci na kritiku teze emotivistů, že hodnotící soudy mají pouze emotivní nikoli deskriptivní význam, shodují se emotivisté i expresivisté v tom, že hodnotící soudy nevypovídají nic o vnější skutečnosti, ale že vyjadřují pouze mentální, resp. psychické stavy mluvčího. ${ }^{54}$

Jako alternativu k expresivismu (a emotivismu) staví MacIntyre vlastní pojetí významu hodnotících soudů a predikátů, které se podstatně neliší od pojetí, které představil již ve Ztrátě ctnosti. Podle tohoto pojetí hodnotící a normativní soudy vypovídají o určitých faktech, a mohou být tedy pravdivé i nepravdivé. Měřítkem hodnocení je podle tohoto pozdního pojetí, stejně jako ve Ztrátě ctnosti, míra zdařilosti fungování předmětu hodnocení v určitém teleologicky vymezeném rámci. Zatímco však ve Ztrátě ctnosti jsou tímto rámcem společenské praxe, potažmo osobním příběhem současně vyložený i sjednocený celek lidského života, v MacIntyrově posledním díle je tímto rámcem zdařilý lidský

51 Podle Charlese C. Stevensona, autora klasické formulace emotivismu, vyjadřují hodnotící soudy souhlas či nesouhlas a mají tzv. emotivní význam. Soudy, které mají emotivní význam, neříkají nic o světě, a nemohou být tedy pravdivé či nepravdivé. To mohou být pouze soudy, které mají význam deskriptivní. Teze, že hodnotící soudy mají pouze emotivní, a nikoli deskriptivní význam, byla podrobena kritice, která si vynutila reformulaci pojetí významu hodnotících soudů v duchu expresivismu.

52 A. MacIntyre, Ethics in the Conflicts of Modernity, str. 18.

53 Tamt., str. 23.

54 Tamt. 
život (human flourishing) jako celek; dobré je to, co k tomuto zdaru přispívá, zlé je to, co mu brání. ${ }^{55}$

MacIntyre připouští, že zdařilý lidský život má v různých dobách, kulturách, ba u různých jedinců $\mathrm{v}$ téže době a kultuře velmi odlišnou podobu, což se projevuje $\mathrm{v}$ tom, že názory na to, v čem zdar lidského života spočívá, se často liší, a někdy si dokonce odporují. ${ }^{56}$ Podle autora však existuje kritérium, které musí splňovat každý život, pokud má být důvodně považován za zdařilý. Je jím dosažení nejvyššího dobra coby posledního cíle (final end) ${ }^{57}$ Toto dobro má podle MacIntyra čtyři následující znaky: 1) je cílem rozumové činnosti jako takové; 2) jeho dosažení zahrnuje získání vysokého stupně sebepoznání; 3) nespočívá ve slasti, moci, politické cti, penězích či fyzické, intelektuální, mravní, estetické, nebo dokonce duchovní zdatnosti (excellence), 4) má se vůči ostatním dobrům tak, že mají-li tato ostatní dobra své patřičné místo v lidském životě, směřuje člověk ke svému nejvyššímu dobru a naopak, tzn., že směřuje-li člověk ke svému nevyššímu dobru, mají všechna ostatní dobra své patřičné místo v jeho životě. Čím je toto dobro po obsahové stránce? MacIntyre jej vymezuje jako stav, v němž je člověk schopen pravdivě (retrospektivně) poznávat, v čem v životě uspěl a v čem selhal, tzn. stav, v němž je schopen vyprávět pravdivě svůj životní př́iběh. ${ }^{58}$

Co z tohoto pojetí teleologie plyne pro jeho pojetí významu hodnotících soudů a predikátů? Jak jsme uvedli výše, MacIntyre i v tomto svém posledním díle připouští, že zdařilý život coby nejvyšší úběžník lidských hodnocení je historicky, stavovsky a snad i individuálně relativní kategorií, což se projevuje v tom, že i názory na to, v čem zdar lidského života spočívá, se často liší, a někdy si přímo odporují. Pro pojetí významu hodnotících soudů a predikátů z toho logicky plyne, že tyto soudy a predikáty jsou platné pouze relativně, tzn. vzhledem k tomu či onomu pojetí zdařilého lidského života. MacIntyre však současně energicky trvá na existenci životních omylů a z nich pocházejících nezdarů, které pojímá absolutně, nikoli relativně: kniha začíná poukazem na to,

55 Tamt., str. 24-27. Položením důrazu na zdařilý život coby poslední cíl lidského usilování se MacIntyre nedistancuje od staršího pojetí akcentujícího teleologii společenských praxí, nýbrž pouze toto starší sociologicky založené pojetí integruje do metafyzicky založeného rámce zdařilého lidského života coby posledního cíle lidského usilování. Posun od teleologie praxí k teleologii životního zdaru je důsledkem MacIntyrovy revize vlastního filosofického projektu. Viz výše, pozn. 12.

56 Tamt., str. $27,87$.

57 Tamt., str. 53.

58 Tamt., str. 54. 
že lidské životy se mohou různým způsobem a z různých důvodů zhatit, a k tomuto leitmotivu se několikrát znovu vrací. ${ }^{59}$ Jak rozumět tomu, že hodnotící predikáty a soudy mohou být někdy relativní, jindy absolutní?

MacIntyre to bohužel blíže nevysvětluje. Snad je to míněno tak, že hodnocení toho, zda mít, být, konat to či ono je sice relativní vůči určitému pojetí zdařilého lidského života, ale pro Jana Nováka, jehož životní cíl spočívá v tom a tom, může být v určitém specifickém kontextu zkrátka dobré mít, být nebo konat to či ono - a to tehdy, jestliže to (významně) přispívá k jeho životnímu zdaru. Jestliže to tedy Jan nemá, není nebo nekoná, je tuto situaci třeba hodnotit jednoznačně negativně. Toto hodnocení je relativní v tom smyslu, že je provedeno s ohledem na to, co je posledním cílem Janova života.

Pro MacIntyra je ale v diskuzi s expresivisty především důležité zdůraznit, že toto hodnocení nezávisí pouze na mentálních stavech hodnotícího, ale na faktech, které jsou na těchto stavech nezávislé. Přestože je tedy toto pojetí významu hodnotících predikátů a soudů realistické v tom smyslu, že tyto soudy a predikáty vypovídají i o realitě existující mimo mentální stavy toho, kdo hodnocení pronáší, je platnost těchto soudů a predikátů obecně vzato relativní. Nerelativní je pouze v kontextech, kdy je hodnocení prováděno vzhledem $\mathrm{k}$ již více či méně přsesně vymezenému pojetí posledního cíle toho kterého lidského života.

Jak jsme uvedli výše, tento výklad významu hodnotících soudů a predikátů vychází z předpokladu, že hodnotící osoba vytváří své hodnocení na základě odpovědi na otázku, zda a nakolik předmět jejího hodnocení přispívá k dosažení jejího posledního životního cíle. Hledisko posledního cíle a touhy po něm je tedy v MacIntyrově pozdní koncepci nejvyšším úběžníkem hodnocení, jehož projevem jsou hodnotící soudy a predikáty. Z MacIntyrova výkladu je přitom zřejmé, že dobro, kterým je pro každého člověka dosažení jeho posledního cíle, je nazíráno z hlediska jeho skutečného, nikoli pouze domnělého zájmu. Toto přesvědčení je východiskem polemiky s expresionisty, kteří podle MacIntyra nejsou schopni v rámci své koncepce rozlišit mezi tím, v čem u daného člověka zdařilý život skutečně spočívá, a tím, zač jej tento člověk (někdy mylně) považuje. MacIntyre přesvědčivě ukazuje, že vyjadřují-li hodnotící soudy pouze mentální stavy mluvčího, není zde pro toto zásadní rozlišení

59 Srv. zvláště tamt., str. 74 nn., kde MacIntyre rozebírá zdroje omylů v oblasti praktické racionality. Termín „omyl“ (error) je zde použit ve svém původním, absolutistickém smyslu. Po přečtení této pasáže získá čtenář dojem, že „omyly“, o nichž MacIntyre mluví, nejsou pochybení pouze vzhledem k určitému pojetí zdařilého života, tedy omyly secundum quid, nýbrž omyly simpliciter. 
prostor, a proto není ani prostor pro rozlišení mezi pouze domnělým a skutečným posledním cílem daného člověka. Pak ovšem, zdůrazňuje MacIntyre, zde není ani možnost uznat objektivní realitu životních omylů a z nich plynoucích chyb. Ta totiž podle něj spočívá právě v tom, že se člověk svým postojem, činem, popř. nečinností, zčásti či zcela míjí se svým posledním cílem a tedy s možností žít zdařilý život.

Vzhledem k tomuto prvku objektivity, který je obsažen v MacIntyrově pojetí posledního cíle coby nejvyššího měřítka hodnotících soudů a predikátů, lze říci, že MacIntyrovo pojetí je založeno na pojetí dobra v intencích kategorie významnosti, kterou von Hildebrand nazval „objektivním dobrem pro osobu““ ${ }^{60}$ Von Hildebrand ve svých analýzách tzv. tř́i základních kategorií významnosti ukazuje, že objektivní dobro pro osobu vždy předpokládá existenci kategorie významnosti, kterou nazývá „o sobě významné“ či prostě „hodnota“. Že tomu tak bude i v případě MacIntyrova pojetí posledního dobra, lze ukázat následující úvahou:

Neoaristotelik Jan Novák hodnotí své postoje, jednání, touhy a ambice $\mathrm{z}$ toho úhlu pohledu, nakolik napomáhají, popř. zabraňují dosažení posledního cíle jeho života. To znamená, že jsou dobrá natolik, nakolik dosažení tohoto cíle napomáhají, a špatná natolik, nakolik mu brání. Dosažení posledního cíle svého života tedy Jan Novák hodnotí z hlediska jeho objektivní významnosti pro něj. Podobně jeho známá, neoaristotelička Jana Dvořáková, hodnotí dosažení posledního cíle svého života z hlediska jeho objektivní významnosti pro ni. Jan i Jana budou ale pravděpodobně souhlasit s tvrzením, že je žádoucí, aby každý člověk dosáhl svého posledního cíle. Zeptáme-li se, je-li význam slova „žádoucí“ ve větě „Je žádoucí, aby každý člověk dosáhl svého posledního cíle“ stejného druhu jako je význam hodnotícího predikátu ,dobrý“ v hodnoceních, jimiž Jan a Jana hodnotí své postoje, činy, touhy a ambice, odpověd’ bude negativní. Pokud bychom totiž měli nahradit slovo ,žádoucí“ ve větě „Je žádoucí, aby každý dosáhl posledního cíle svého života“, neřekli bychom ,je pro mě, Jana Nováka, žádoucí“ popřr. ,je pro mě, Janu Dvořákovou, žádoucí". Smysl dané věty je totiž ten, že stav světa, o němž vypovídá, je žádoucí „,sám o sobě“, „,sám sebou“, „kvůli sobě samému“ či jak jinak to lze vyjádřit. A takto jej zjevně chápou i Jan a Jana. To ovšem znamená, že předmět žádosti nemusí být vposledku vždy vztažen k tomu, co je žádoucí pro danou osobu, ale může být vztažen k tomu, co je žádoucí samo o sobě. Jan i Jana tedy implicitně přijímají existenci

60 D. von Hildebrand, Christian Ethics, str. 49-65. 
měřítka hodnocení, které není vztaženo k jejich vlastnímu poslednímu cíli a jeho žádoucnosti.

Učiňme v naší úvaze ještě další krok: Pokud Jan a Jana souhlasí s výrokem „Je žádoucí, aby každý člověk dosáhl posledního cíle svého života“, souhlasí nutně i s výrokem „Je žádoucí, abych já, Jan, dosáhl posledního cíle svého života“, resp. „Je žádoucí, abych já, Jana, dosáhla posledního cíle svého života“. Povšimněme si, že v těchto větách může ,žádoucí“ znamenat jak „,samo o sobě žádoucí“ tak ,,pro mě, Jana, žádoucí“, resp. „pro mě, Janu, žádoucí“. Tato významová duplicita je pak prrítomna, jak z perspektivy toho, o kom věta vypovídá, tak z perspektivy jiné osoby. Jana může větu chápat tak, že je pro ni žádoucí, aby dosáhla svého posledního cíle, ale současně i tak, že je o sobě žádoucí, aby se tak stalo. A Jan může tutéž větu chápat bud’ tak, že říká, že je (o sobě) žádoucí, aby Jana dosáhla svého posledního cíle, tak i v tom smyslu, že je pro Janu žádoucí, aby tohoto cíle dosáhla.

Podíváme-li se nyní, jaký je vztah mezi oběma možnými výklady analyzované věty, můžeme konstatovat následující logický vztah: jelikož je o sobě dobré, aby Jana dosáhla svého posledního cíle, je to dobré i pro ni. Přes tuto logickou závislost hlediska „dobrého pro osobu“ na „dobrém o sobě“ je však z hlediska motivace vztah mezi oběma hledisky opačný. Usiluje-li Jana o dosažení svého posledního cíle, činí tak především proto, že ví, že je to pro ni dobré, ba nanejvýš dobré, a až poměrně druhotně proto, že ví, že je (o sobě) dobré, aby, tak jako každý druhý, i ona dosáhla svého posledního cíle.

K čemu tato subtilní argumentace v rámci diskuze MacIntyrova pojetí významu hodnotících soudů a predikátů? Naznačme to hlavní. MacIntyre, jak se zdá, nerozlišuje hledisko „dobrého o sobě“ a „objektivně dobrého pro osobu“. Na problematiku dobra se dívá teleologicky, dobro chápe jako cíl, a tedy jako předmět racionální (i iracionální) žádosti. Výše uvedená úvaha však ukázala, že dobro, které je cílem, protože přitahuje naši žádost, je logicky (i ontologicky) závislé na dobru, které není žádoucí, protože vzbuzuje naši žádostivost, ale pro svou vnitřní hodnotnost. Jak ukazuje von Hildebrandova verze materiální hodnotové etiky, na kategorii o sobě významného a vztahu patřičnosti (Gebührensbeziehung), který zakládá, lze postavit koncepci universálně platné etické normativity. ${ }^{61}$ Je-li ovšem, jako u MacIntyra, centrální kategorií

61 Základní logiku tohoto přístupu jsem vysvětlil v M. Cajthaml, Dietrich von Hildebrand's Moral Epistemology, in: American Catholic Philosophical Quarterly, 92, 4, 2018, str. 626-627. K metafyzicko-epistemologickým předpokladům tohoto přístupu viz tamt., str. 627-632. 
významnosti objektivní dobro pro osobu, navíc chápané jako poslední cíl dané osoby, jehož obsah je historicko-kulturně, stavovsky a částečně i individuálně relativní, nebude sice na něm založená etická normativita subjektivní ve smyslu expresivismu či emotivismu, ale nebude ani universálně platná.

MacIntyra tato skutečnost nezneklidňuje. Snahu o universálně a racionálně založenou morálku totiž ztotožňuje s projektem osvícenské morálky, který podle jeho slov ve Ztrátě ctnosti nejen fakticky selhal, ale selhat musel. ${ }^{62}$ Ve svém posledním díle se snaží ukázat, že to, co Hume považoval za universální, protože pro všechny lidi přirozené city, jsou ve skutečnosti pouze city jeho doby a (privilegované) společenské skupiny, jíž byl členem, a že tedy zdůvodnění morálky založené na těchto citech není universálně platné, jak se Hume domníval. ${ }^{63} \mathrm{~V}$ tom má pravdu. Je ale každá metaetická teorie pracující s koncepcí universálně platných norem výrazem „falešného vědomí" moderních společenských elit? Zdá se, že MacIntyre je přinejmenším nakloněn tuto otázku zodpovědět kladně. Tato tendence se projevuje i v interpretačním př́istupu ke klasické etice. Není jistě náhodou, že MacIntyre ve svém výkladu Aristotela a Tomáše nepřebírá jejich universalistická pojetí posledního cíle člověka, at' už jím je rozumové nazírání po vzoru božské noesis nebo křest'anská visio beatifica. Podobně zapadá v jeho jinak působivém výkladu Aristotela i Tomáše skutečnost, že oba znají výše uvedené základní rozlišení mezi „o sobě dobrým“ a „dobrým pro osobu“, tedy dobrem, které nepodmíněně vyžaduje, a tím, které získává svou závaznost teprve v kontextu našeho usilování o zdařilý život. ${ }^{64}$

MacIntyrův výklad významu hodnotících predikátů a soudů $\mathrm{v}$ jeho posledním díle by mohl být rozšriřen o kategorii o sobě významného, pokud by jeho autor vyvodil patřičné důsledky ze svého pojetí společného dobra ${ }^{65}$ Zdá se totiž, že společné dobro, o němž se poměrně obsáh-

\footnotetext{
62 A. MacIntyre, Ztráta ctnosti, str. 68-80.

63 Týž, Ethics in the Conflicts of Modernity, str. 79-85.

64 Pokud jde o Aristotela, srv. M. Cajthaml, Von Hildebrand's Concept of Value, in: Studia Neoaristotelica , 15, 1, 2018, str. 116-127. V př́ípadě Tomáše, srv. M. Waldstein, Dietrich von Hildebrand and St. Thomas Aquinas on Goodness and Happiness.

65 Společné dobro je takové, jehož dosažení není možné jednotlivci jakožto jednotlivci, ale které lze uskutečnit pouze společným úsilím více jednotlivců, tedy např́íklad dobro rodinného života nebo provedení symfonie. A. MacIntyre, Ethics in the Conflicts of Modernity, str. 169.
} 
le rozepisuje v druhém článku čtvrté kapitoly své knihy ${ }^{66}$ a které hraje velmi důležitou roli $\mathrm{v}$ jeho celkovém pojetí etiky a politiky, je chtěno kvůli sobě samému, nikoli jako prostředek k dosažení posledního cíle jednotlivců, jejichž společným dobrem je. MacIntyre sice nemůže takové tvrzení explicitně formulovat, protože nerozlišuje objektivní dobro pro osobu a to, co je dobré o sobě. Nenaznačuje však, že úsilí o společné dobro má být pojato čistě jako prostředek k dosažení nejvyšších dober individuí, která mají na daném společném dobru účast. ${ }^{67}$ MacIntyrovi je tedy možné rozumět tak, že vztah mezi společným dobrem určitých jedinců a jejich jednotlivými nejvyššími dobry je takový, že společné dobro je chtěno jak proto, že je o sobě dobré, tak proto, že je rozpoznáno jako dobré pro osobu, která o něj usiluje. Jak bylo ale uvedeno, jedná se pouze o spekulativní výklad, protože MacIntyre hledisko o sobě dobrého a dobrého pro osobu výslovně nerozlišuje.

\section{Závěr}

Vrat'me se nyní k základní otázce, kterou jsme v tomto článku položili: Lze na základě výkladu etiky ctností předloženém ve Ztrátě ctnosti ospravedlnit existenci, popř. platnost mravních norem? Z výše uvedeného je zřejmé, že MacIntyrův výklad etiky ctností ve Ztrátě ctnosti sotva nabízí konceptuální zdroje umožňující zdůvodnit platnost takových norem, které by byly současně mravní, universálně platné a nepodmíněné. Tento závěr platí přesto, že MacIntyre přesvědčivě ukazuje, že normy lze $\mathrm{v}$ principu platně vyvozovat $\mathrm{z}$ faktů, že teleologie praxí zakládá platnost určitých norem a že určité normy lze vyvozovat $\mathrm{z}$ teleologie narativně konstituovaného životního smyslu.

Tím nechceme tvrdit, že MacIntyre měl v úmyslu obhájit robustnější pojetí etické normativity než ve skutečnosti obhájil. MacIntyre, ve Ztrátě ctnosti i v pozdějších textech, je podle všeho přesvědčen, že jeho pojetí neoaristotelské etiky a politiky nepotřebuje více etické normativity, než

66 Tamt., str. 168-175.

67 Nejjasněji se autor v této věci vyjadřuje, když říká, že dosažení vlastního dobra je možné ,ppouze skrze usilování o dobro společné“ (that it is only through directing themselves toward the achievement of common goods that they are able to direct themselves toward the achievement of their own good qua individual). Tamt., str. 175. Tato formulace sice není jednoznačná, je ale možné jí rozumět tak, že společné dobro je chtěno jak pro ně samé, tak pro jeho potřebnost pro dosažení dobra individuálního. 
kolik je pro ni schopen vyargumentovat. Toto přesvědčení je výsledkem propojení celé řady komplexních myšlenkových motivů, které zde není možné rozebírat. Omezím se proto na pouhé vyjmenování tří hlavních motivů.

Z epistemologického hlediska je to MacIntyrova specifická forma nedogmatického non-kognitivismu implikovaného $v$ jeho pojetí vědy. Dokonalá věda (perfected science), tzn. věda, která obsahuje definitivní poznatky (achieved understanding), je pouze teleologickou ideou nedokonalé tady a ted' provozované vědy ${ }^{68}$ Poznatky této nedokonalé vědy jsou, alespoň v etice, $v$ drtivé většině pouze pravděpodobné.$^{69} \mathrm{Z}$ politického hlediska je to program neoaristotelské politiky založené na sdíleném úsilí o společné dobro coby alternativy k novověkému společensko-ekonomicko-politickému řádu založenému na tržním hospodářství a liberální demokracii. ${ }^{70} \mathrm{~S}$ touto Marxem i Aristotelem inspirovanou radikální kritikou moderní doby se pojí neméně radikální kritika novověké racionality. Jejím cílem jsou především novověké pokusy o racionální založení morálky. Jsou-li hlavními cíli společensko-ekonomicko-politické kritiky Adam Smith a Isaiah Berlin, mîrí kritika novověkých etických teorií především na Kanta a Milla. Domníváme se, že čím více bude čtenár MacIntyrových textů sdílet tato jeho obecná stanoviska, tím více bude mít tendenci být spokojen s jeho pojetím etické normativity. Totéž ovšem platí i opačně: čím kritičtější bude k jeho epistemologii, politice, potažmo ke kritice novověké racionality, tím bude vůči tomu či onomu aspektu jeho pojetí etické normativity obežretnější.

Není pochyb o tom, že MacIntyrovo dílo má zásadní hodnotu coby jeden z nejpromyšlenějších eticko-politických konceptů současnosti, který má ambici být přesvědčivou alternativou k politicko-ekonomicko-filosofické moderně a postmoderně. Právě proto si však zaslouží, aby byl čten kriticky, a to nejen na rovině čisté filosofické teorie, ale i na rovině svých společensko-ekonomicko-politických důsledků a dopadů. Proto jsme článek zahájili zmínkou o důsledcích, které má MacIntyrův politicko-sociálně-etický koncept pro otázku lidských práv. K tomuto východisku se nyní vracíme. Jan Patočka $\mathrm{v}$ jednom z doprovodných textů k Chartě 77 napsal: „Lidé dnes zase vědí, že existují věci, pro které stojí za to trpět, a že věci, pro které se eventuálně trpí, jsou ty, pro které

68 Viz literatura v pozn. 42.

69 Viz literatura v pozn. 43.

70 Srv. A. MacIntyre, Ethics in the Conflicts of Modernity, kap. 2-4, passim. 
stojí za to žít." ${ }^{71}$ Jsou-li lidská, resp. občanská práva pouhou iluzí, byt' někdy užitečnou, jak MacIntyre tvrdí a jak to více méně vyplývá z jeho politicko-socio-etického konceptu, lze důvodně oponovat tvrzení, že Patočka trpěl za iluzi? A formulováno opačně: jestliže Jan Patočka netrpěl za iluzi, není třeba některé prvky MacIntyrovy filosofické koncepce odmítnout, resp. modifikovat? Tento článek je třeba vidět na tomto pozadí, tedy jako $\mathrm{v}$ mnoha ohledech omezený a celkovému nároku jistě nedostačující pokus o takovou korekturu. ${ }^{72}$

\section{ZUSAMMENFASSUNG}

Das Hauptanliegen des Artikels besteht darin, eine Antwort auf die Frage zu finden, welche Form der ethischen Normativität die sozial fundierte Teleologie impliziert, die in MacIntyres berühmten Werk After Virtue entwickelt wurde. Der vorliegende Artikel versucht diese Normativität zu rekonstruieren und zugleich deren Kritik zu bieten. Dabei wird auch die spätere Entwicklung des Autors berücksichtigt, die durch seine Hinwendung zum Thomismus gekennzeichnet ist. Der Thomismus wird von MacIntyre zugleich als Grundlage für die metaphysische Rechtfertigung der Normen benutzt. Deshalb wird auch MacIntyres Interpretation der Werturteile und Wertpredikate berücksichtigt, die in seinem Spätwerk Ethics in the Conflicts of Modernity vorgeschlagen wurde. Im Bezug auf After Virtue wird MacIntyres Kritik an der Behauptung Humes behandelt, dass von den Tatsachen nicht auf die Normen geschlossen werden kann. Es wird ebenso eine Analyse von MacIntyres Auffassung von Tugend, sozialer Praxis, Erzählung und Tradition vorgenommen, die eine ethische Normativität bewerkstelligen sollen. Weiterhin wird gezeigt, in welchem Sinn MacIntyre's Auffassung der Werturteile und Wertpredikate, die in seinem Spätwerk enthalten ist, realistisch, und in welchem es hingegen relativistisch ist. Der Artikel kommt zu dem Schluss, dass MacIntyres Konzeption der Tugendethik in After Virtue eine unzureichende konzeptuelle Grundlage für die Rechtfertigung der Gültigkeit von Normen bietet, die moralisch, allgemein gültig und unbedingt wären. Es wird auch dargelegt, aus welchen Gründen MacIntyre sein eigenes

71 J. Patočka, Co můžeme očekávat od Charty 77?, in: týž, Češi, I, Sebrané spisy, XII, vyd. K. Palek - I. Chvatík, Praha 2006, str. 443.

72 Studie je výstupem výzkumného projektu GA ČR 18-06856S, Hodnota a teleologie - Dialog mezi materiální hodnotovou etikou a tradiční etikou. 
Konzept der ethischen Normativität als befriedigend betrachtet. Es liegt am Leser selbst, sich ein eigenes Urteil über diese Gründe zu bilden.

\section{SUMMARY}

The main objective of the article is to answer the question what form of ethical normativity is implied by the socially based teleology of MacIntyre's After Virtue. The article reconstructs this normativity and provides its critique. It also takes into account author's later development, characterized by his inclination to tomism which the author uses as a basis for metaphysical justification of norms. Regarding this point, the article critically assesses MacIntyre's interpretation of the evaluation judgments and predicates in the later work Ethics in the Conflicts of Modernity. Regarding After Virtue, the article deals with MacIntyre's critique of Hume's claim that norms cannot be inferred from the facts. It also furnishes an analysis of MacIntyre's concepts of virtue, social practice, narrative and tradition which are supposed to establish ethical normativity. Regarding the analysis of MacIntyre's conception of value judgments and predicates in his latest work, the article explains in what sense this conception is realistic and in what sense it is relativistic. The article concludes that MacIntyre's conception of virtue ethics in After Virtue does not provide conceptual basis for justifying the validity of norms which would be moral, universally valid and unconditional. 